\title{
GENDER AND "MODERN" CONSTITUTIONALISM: THE TREATY ESTABLISHING A CONSTITUTION FOR EUROPE
}

\author{
Dr Charlotte Skeet, Lecturer in Law at Sussex Law School, \\ University of Sussex
}

\begin{abstract}
This paper takes as its starting point the understanding that constitutions and constitutional processes are gendered and that different constitutional forms may have different consequences for women as citizens. The paper then reflects on the gender gap revealed by the recent referenda on the Treaty Establishing a Constitution for Europe (Constitutional Treaty) in France and the Netherlands. In these referenda women led the "no" vote against the Constitutional Treaty. The paper looks at the involvement of women in the drafting process, reviews feminist critique of the Constitutional Treaty and analyses the gendered nature of the current European constitutional project, to address why women said "no" to the Constitutional Treaty. Moreover, by relating feminist critique to wider issues around the constitutional form embodied by the Constitutional Treaty, the paper goes beyond questions of participation in the process and content of the Treat. It argues that the type of constitutional settlement which the Constitutional Treaty sought to introduce are inimical to gender justice. $^{1}$
\end{abstract}

\section{Introduction}

The Treaty Establishing a Constitution for Europe (Constitutional Treaty) was drafted, amended, and debated through the Convention on the Future of Europe, February 2002 - July 2003 and the subsequent Inter-Governmental Conferences, October 2003 - June 2004. The Constitutional Treaty was signed in October 2004 and was intended to replace previous European Union treaties signed over the last 50 years. $^{2}$ While some governments stated that accession would be a purely governmental matter others offered their citizens referendums. ${ }^{3}$ An official "toolkit" for citizens on the Constitutional Treaty suggested that "Only the support and the participation of the 450 millions citizens who make up the European Union will make this Europe a reality. Regardless of the method of ratification of the Constitution.

1 This is based on a paper given at the University of Sussex / University of Bergamo Legal Forum September 172005.

2 With the exception of the EUROTOM, http://Europa.eu/constitution/index_en.htm

3 Ten states announced that they would allow referendums. But only in Spain, Luxembourg, France and The Netherlands did referendums take place before the process was halted. 
..." While in Spain and Luxembourg the referenda outcomes were in favour of the Constitutional Treaty both French and Dutch citizens sent back a clear "no". 5 This had inevitable ramifications. 6 Two weeks later the remaining referenda were placed on hold and it is now widely accepted that the Constitutional Treaty has been set to one side.

It is less recognised that the voting in Holland showed a clear gender gap with around $66 \%$ of women voting "no" compared to $58 \%$ of men. ${ }^{7}$ Some evidence also suggests that in the French referendum women led in the "no" vote. ${ }^{8}$ Certainly France was the focus of concerted campaigning by feminist groups against the Constitutional Treaty. There have been previous feminist campaigns against constitutional changes in Europe. In Sweden there were feminist campaigns against monetary union and women led in the "no" vote which defeated the EMU. ${ }^{9}$ The vote on the Maastricht Treaty in France was also close and showed women more likely to vote "no" than men. ${ }^{10}$ But the feminist campaign against the Constitutional Treaty was trans-national with Europe wide conferences and initiatives. Well-documented criticisms from academics and European feminist lobbies of the draft versions and of the final Constitutional Treaty fed into feminist and socialist-feminist campaigns against the Constitutional Treaty.

To many UK feminists this anti-Treaty stance might initially seem surprising. In the United Kingdom there is a clear history charting the importance of the EU in developing women's equality and in increasing awareness of constitutionalism as an equality tool for feminists. ${ }^{11}$ This paper will not argue that all feminists voted "no" or that all the women who so voted were feminists, but it will address the issue of why there was a women's campaign against the Constitutional Treaty and how this fits into

4 Information Tools on the Constitution, Brussels, $11^{\text {th }}$ August, 2005 http://europa. eu/constitution/download/Catalogue_EN.pdf , 1.

5 Respectively $55 \%$ and $62 \%$ overall.

6 H. H. Joseph Weiler, On the Power of the Word: Europe's Constitutional Iconography (2005) 3:2 International Journal of Constitutional Law, 173, considered that if such a vote occurred the Treaty would have to be set aside.

7 Austin, Greg and Grace Annan, Gary Hindle and Kate Parker, Reform in the Europe after the 2005 Referendums: Battling for the Results: Policy Brief, Foreign Policy Centre June 9 2005, www.fpc.org.uk/publications, at 8.

8 A series of IPSOS polls leading up to the vote suggested women and the poor were much more likely to vote "no" than men. America Vera-Zavala, a Swedish journalist and member of ATTAC cites these in her article "French Vote on European Constitution" ZNet, May 29 2006, www.zmag.org/content. However Sylvain Brouard, and Vincent Tiberj, "The French Referendum: The Not So Simple Art of Saying Nay," American Political Science Association online, PSOnline www.apsanet.org /content_24661.cfm, cite the IPSOS exit Poll on the May 292005 which revealed the "no" vote from women slightly behind men 53\% to $57 \%$.

9 Nicholas Aylott, The Sweden referendum on EMU of September 14 2003: Referendum Briefing No.9 EPERN, http://www.sussex.ac.uk/sei/documents/ epernbrefsweden.pdf at 4.

10 Brourd + Tiberj, "The French Referendum" (2006), at 262

11 E.g. in the UK, women's activism in the Scottish Constitutional Convention and in the Northern Ireland peace talks. Elizabeth Meehan, Women's Rights in Citizen Europe, in The Manchester Papers: http://www.charter88.org.uk/pubs/manpaps /meehan.html. 
theoretical understandings of the relationship between constitutions and gender.

The next section examines the wider debate on gender and constitutionalism and asks whether political movements like feminism should ever seek a stronger constitutionalism. The following sections explore women's participation in drafting the Constitutional Treaty and considers subsequent criticisms and the campaign for a "no" vote. Finally feminist opposition to the Constitutional Treaty is examined in light of the Constitutional form it sought to introduce.

\section{Gender and Constitutional Theory}

The understanding of constitutions as gendered and impacting differentially on men and women is recognised by a wide variety of organisations ${ }^{12}$ and is supported by a wide literature on women, constitutions, constitutional interpretation and constitutional change. ${ }^{13}$ The different operation of constitutions for men and women may be evidenced in a number of ways. For instance statements of who is and is not a citizen, and rights framing and implementation may be gendered. ${ }^{14}$ The way that constitutions distribute power - who exercises power and where it is exercised may have a differential impact for women; ${ }^{15}$ women's access to political process may vary at local, national or state/federal level. The anticipated reach of constitutional provisions, or the way constitutions divide powers may re-

12 Including the EU, the UN, UNDP, UNIFEM the World Bank, Amnesty International, Human Rights Watch among others.

13 For instance, Beverley Baines, and Ruth Rubio-Marin (eds.), The Gender of Constitutional Jurisprudence (CUP, 2005); Christine Chinkin, Gender Mainstreaming in Legal and Constitutional Affairs: A Reference Manual for Government and Other Stakeholders, Commonwealth Secretariat, London, 2001; Dobrowolsky, Alexandra and Vivien Hart, Women Making Constitutions: New Politics and Comparative Perspectives (2003); Shah, Niaz, The Constitution of Afghanistan and Women's Rights, [2005] 13 FLS 239; Gill Vickers, Why Should Women Care About Constitutional Reform, in David Schneiderman, (ed.), Conversation Among Friends: Interdisciplinary Conference on Women and Constitutional Reform (1991). Ralph Sandland, "Between "Truth" and "Difference": Post-structuralism, Law and the Power of Feminism" [1995] 31 FLS 47; Catherine Dauvergne, A Reassessment of the Effects of a Constitutional Charter of Rights on the Discourse of Sexual Violence in Canada, (1994) 22 International Journal of the Sociology of Law 291; Constitutional Equality: The Implication For Women in South Africa, (1995) Summer Social Politics 208; Kim Scheppele, Constitutionalising Abortion, in Marianne Githens, and Dorothy McBride Stetson, (eds.), Abortion Politics: Public Policy in Cross- Cultural Perspective (1996); Human Rights Watch: Woman's Watch, www.hrw.org/women/; Women's Human Rights Net, www.whrnet.org; Minority Rights Group International www.minorityrights.org.

14 For examples see Rebecca Cook, Human Rights of Women: National and International Perspectives (1994); Patricia Grimshaw, Katie Holmes and Marilyn Lake, (eds.), Women's Rights and Human Rights: International Historical Perspectives (2001); Joanna Kerr, (ed.), Ours By Right: Women's Rights as Human Rights (1993).

15 Gill Vickers, "Why Should Women Care About Constitutional Reform" in Schneiderman, David, (ed.), Conversation Among Friends: Interdisciplinary Conference on Women and Constitutional Reform (1991). 
enforce the public/private divide. Activities may or may not be covered by rights instruments and other constitutional provisions depending on where they take place. ${ }^{16}$ Finally, since women are over-represented among the poor, provision (or not) for welfare rights and other shared social goods will have particular resonance for women. ${ }^{17}$

In addition to the differential impact of constitutions on men and women, questions arise about the very nature of constitutionalism and how constitutionalism serves women as a group. In considering different types of constitutionalism the next section examines critiques of "modern" constitutionalism in relation to women and considers how understandings of the extant European Union constitution fits into these theoretical understandings.

This feminist query about the nature of constitutionalism itself stems, in part, from a longstanding feminist critique of constitutionalism and the "modern" constitutional form, which is said to date from the United States of America Constitutional Convention and Constitution $1787 .{ }^{18}$ There is also an historical failure of constitutions and constitution making to reflect the concerns of women and other excluded groups. The history of constitutions can be seen as a history of the categorisation and exclusion of certain groups, either through imperial projects or internally through the construction of a citizenship. ${ }^{19}$ This, Iris Marion Young argues, has prevented the full recognition of women and denied black and indigenous peoples an identity as citizens in the US; and has operated similarly against women, Jews and the lower socio-economic classes in Europe. ${ }^{20}$ Alan Cairns iterates twentieth century exclusions of certain groups, referring to the phenomenon as "constitutional stigmatisation."21

Yet some traditional constitutional theorists do not view changes concerning women's political equality as constitutional changes at all, because they impact more on the relationship amongst the governed rather than between

16 For instance Attorney General of Canada v Attorney General of Quebec [2005] S.C.J. no 57 and in the UK, $R$ v Leonard Cheshire Foundation (a Charity) \& HM Attorney-General [2002] EWCA Civ. 36621 March 2002.

17 For evidence of this in the UK, which is not atypical, see Frances Katie Drever, Joanna Brown Fisher, and Jenny Clark, Social Inequalities (London, National Statistics Office, 2000).

18 Abigail Adams, (S Mitchell Editor) New Letters Of Abigail Adams:1788-1801 (1947); Kingdom, Elizabeth," Gendering Rights" in Andre Jean Arnaurd, and Elizabeth Kingdom,(eds.)Women's Rights and the Rights of Man (1990) Sandra Van-Burkleo, Belonging to the People: Women's Rights and American Constitutional Culture (2001). Sylvana Tomaselli, (ed.), Mary Wollstonecraft,- A Vindication of the Rights of Man and A Vindication of the Rights of Women (1792) (Cambridge, Cambridge University Press, 1995), Stopes, Charlotte Carmichael, The Sphere of "Man": In Relation to that of "Woman" In the Constitution (1908).

19 James Tully, Strange Multiplicity: Constitutionalism in an Age of Diversity (1995), p.179-180.

20 Iris Marion Young, Polity and Group Difference: A Critique of the Ideal of Universal Citizenship, in Sunstein, Cass, (ed.), Feminism and Political Theory (1989).

21 Alan Cairns, Constitutional Stigmatisation, in Patrick Hanafin, and Melissa Williams, Identity, Rights and Constitutional Transformation (1999). 
the governed and government. ${ }^{22}$ In contrast, Canadian constitutionalist, James Tully, makes an analogy between the claims of aboriginal peoples arguing for self-determination and the claims of women arguing for equality provisions. He argues both can be viewed as claims for cultural recognition within constitutionalism, ${ }^{23}$ and suggests that equality claims are central to questions of legitimacy within a nation or a political institution. ${ }^{24}$ Tully suggests that although amendments to constitutions gave some recognition to equality groups seeking groups they rarely changed the dominant and exclusionary language of modern constitutionalism. He therefore concludes that the "modern" constitutional form, ${ }^{25}$ with its narrow understandings of the purpose and nature of constitutions, cannot do justice to demands from women and other previously excluded groups. ${ }^{26}$

In descriptions and understandings of "modern" constitutions the principles for legitimate government are usually envisaged as a regulator or limiter of the political process. ${ }^{27}$ Neil Walker critiques dominant norms in constitutionalism from the meta-constitutional perspective of the European Union; Tully from the position of sub-national groups; but their critiques are similar. Both hold that conventions in the dominant language of constitutionalism operate to either assimilate or exclude cultural diversity. Tully argues that conceptions of popular sovereignty serve to exclude diversity from the democratic process. ${ }^{28}$ These conceptions include the myth of a homogenous citizenship, concepts of "a common good," and of a universal equality which transcends difference. While modern constitutionalism pretends neutrality, Walker states that its normative bias favours certain interests and ideas at the expense of others. ${ }^{29}$ The constitutional state is presented as connected to "identity," an "imaginary community" to which people must belong if they are to be considered citizens.

22 In the 1999 Hamlyn lectures, Anthony King argued that the extension of the franchise to women in the UK between 1918 and 1928, while "undoubtedly desirable .... and undoubtedly important to large numbers of women," was "probably not" constitutional change. Anthony King, Does the United Kingdom Still Have a Constitution? (2001), p.1. King argues that this is because the extension of the franchise does not substantially alter the relationship between the governors and the governed. He makes a football analogy: The offside rule in football is fundamental to the game, however, the rule stating that a coin is to be tossed to decide who goes first is not. In his view the extension of the franchise to women is like the rule relating to the tossing of a coin. I don't think football is necessarily the best analogy but staying with it I argue that franchise change is very much like the offside rule both raise questions of legitimacy which are fundamental.

23 Tully, Strange Multiplicity (1995), p.39.

24 Though Judith Squires warns that the process of constitutionalising difference in the form of representational guarantees may "rigidify what are actually very fluid identities," in "Liberal Constitutionalism, Identity and Difference" (1996) XLIV Political Studies 620 at 633.

25 Dating from the US constitutional Convention at Philadelphia 1787.

26 Tully, Strange Multiplicity (1995), p.16.

27 Kenneth Wheare. C Modern Constitutions (OUP, 1960).

28 Tully, Strange Multiplicity (1995), p.64.

29 Neil Walker, 'The Idea of Constitutional Pluralism,' (2002) 65 MLR 317 at 324326. 
The identification of the classical constitution with specifically European origins also aligns constitutions to the state and constitutions are contrasted with "stateless, irregular and ancient societies." ${ }^{\text {"30 }}$ Walker suggests that binding constitutions to this statist framework prevents modern constitutional theory from being able to explain, contain or steer the major flows of political, economic and social power that "escape the state." 31 Walker also notes the exploitation of constitutionalism as a symbolic authority to clothe the aspirations and ideas of politicians with a greater legitimacy. Similarly, Tully critiques presentations of constitutionalism which view the constitution as a pre-condition and not a product of democracy, a mechanism to legitimate politics, when in fact political machinery is needed to legitimate constitutional arrangements. ${ }^{32}$ Finally, Walker critiques what he calls "constitutional fetishism" by which he means overstating the impact of constitutional discourse to the extent that insufficient attention is given to other mechanisms that wield power in society. ${ }^{33}$ All these critiques reveal a constitutional form that disadvantages women and other political minorities, politically, economically and socially.

But this model of the constitution as the only constitutional form is contested. Other models presented by authors who reject this "modern" form show that constitutionalism can present positive opportunities for women and other political minorities. For instance Walker and Tully see constitutions not just as isolated frameworks, which underpin representative democracy, but as themselves caught up in the "dynamics of social and political life." 34 Both believe that constitutionalism has the potential for a radical and transformative form where it is informed by the constitutional convention of mutual recognition, legitimated by political discussion and debate, not viewed as an abstract above politics.

The authors, and others taking this wider view, give historical and current examples of constitutional models that they believe to do this. ${ }^{35}$ Craig for

30 Tully, Strange Multiplicity (1995), p.68.

31 Walker, "Constitutional Pluralism," (2002) at 318-321. Though Himsworth notes that it is precisely the failure to describe and conceive of the state fully in the UK which has led to problems with the UK constitution. Himsworth, Christopher, "In a State No Longer: The End of Constitutionalism" [1996] PL 639

32 ibid., at 649.

33 Walker, "Constitutional Pluralism" (2002) at pp.324-326.

34 Tully, James "Radical Democratic Constitutionalism," paper presented at the Conference on Constitutionalism in Transition University of Leeds, 5th July 2001, p.1. This view of constitutions as inside rather than external to the political framework is also expressed by Richard Bellamy, and Dario Castiglione, in "Introduction: Constitutions and Politics" (1996) XLIV Political Studies 413 and Richard Bellamy, "The Political Form of the Constitution: The Separation of Powers, Rights and Democracy" (1996) XLIV Political Studies 620.

35 Tully, Strange Multiplicity (1995) and Walker, "Constitutional Pluralism.” (2002). Examples cited by Tully include the 1774 Quebec Act, which brought Quebec into the then British Empire. Also Patrick Glen, in Legal Traditions of the World, (OUP, 2000) p.81 provides a more recent example and suggests New Zealand Land's Tribunal established for the adjudication of chthonic land claims is a "looser," more inclusive form of constitutional structure within the "modern" constitutional state. The current South African Constitution, highly praised as a 
instance suggests that before the modern concept of constitutions came to be applied to the British Common Law constitution in the $19^{\text {th }}$ century, the constitution operated to regulate activity between groups and individuals rather than focussing on state institutions. He states that this earlier operation meant that:

". . . the courts did not reason on the basis of any rigid dichotomy between public and private law. They were therefore able to control power based on sound normative principles without necessarily being limited by its source." 36

Charlotte Stopes writing at the end of the $19^{\text {th }}$ century provided historical examples for her argument that the British constitution did not discriminate against women as a group. Rather, she suggested, the discrimination came from a particular line of misinterpretation by male lawyers and judges in the $18^{\text {th }}$ and $19^{\text {th }}$ centuries. $^{37}$

Currently within Europe, the Good Friday Agreement in Northern Ireland provides a further illustration of the concept of "mutual recognition." The agreement recognises "within the authoritative tradition" the legitimacy of alternative constitutional visions belonging to the UK and the Republic of Ireland..$^{38}$ A similar type of agreement, recognising both the legitimacy of UK sovereignty and that claimed by Spain, is proposed for Gibraltar. ${ }^{39}$ In terms of European regional arrangements, the European Convention on Human Rights (ECHR) system recognises a multiplicity of co-existing constitutional arrangements. The qualifiers and limiters that define the scope of rights within the European Convention on Human Rights and Fundamental Freedoms and the principle of "margin of appreciation" applied by the European Court of Human Rights acknowledge a multiplicity of legislative rules, customs, and cultures. ${ }^{40}$

model for constitution making, is said to embody the idea of the constitution as process and in this way bucks the modern constitutional fetish for fixity.

36 Paul Craig, "Public Law, Political Theory and Legal Theory" [2000] Public Law 211. This is also by Sir Stephen Sedley in, The Making and Remaking of the Constitution (1997) and this theory fits with Wittgenstein's view of the Common law constitution as pluralistic. Pitkin, Hanna Fenichel Wittgenstein and Justice (1972) p.52.

37 Stopes, Charlotte Carmichael ,The Sphere of 'Man' in relation to that of 'Woman' in the Constitution (1908).

38 Walker, "Constitutional Pluralism," (2002), at 34; The Good Friday Agreement, http://www.nio.gov.uk/the-agreement.

39 Tony Blair, Hansard Official Report, House of Commons, 20 March 2002, Vol. 382 c. 300 . Notable in both situations is the recognition of the role of politics. In each case more than one sovereign country is involved and change must be legitimated by reference to the people. They operate at both meta-state and substate level, with much wider scope than that envisaged by proponents of the traditional view of constitutions.

40 But the ECHR system may be much better in its recognition of states than of other groupings. For instance there is criticism about the ability of the European Court of Human Rights to recognise the rights of minority religions and lifestyles within states. See Marie-Benedict Dembour, "The Cases That Were Not To Be: Explaining the Dearth of Case-Law on Freedom of Religion at Strasbourg" in Italo Prado, (ed.), Morals of Legitimacy: Between Agency and System (2000). 
Most importantly a number of theorists note that the distinct nature of the European Union's extant constitution seems to fit this concept of mutual recognition. ${ }^{41}$ For instance Walker, writing prior to the Convention On The Future of Europe, argues that the "search for meta-constitutional authority" within the European Union "freed up debate" and encouraged greater resort to "the ample tool-kit of state constitutionalism." 42 The extant European Union constitution, by constantly seeking legitimacy through its operation and process, arguably fits the discursive constitutional model and provides a space for discussion of gender. This does not suggest that the current political structures are the best in terms of their accommodation and facilitation of debate: the machinery of the European Union was not established to respond to democratic demands and is in need of change, but in terms of constitutive form it is forward looking. Bellamy states for instance that the extant constitution is neither based on closed agreed European Union norms and purposes nor on the concept of a fixed sovereign people, two models of nation state constitutions common within Europe. ${ }^{43}$ Instead it has developed from notions of neo-republican governance and the evolution of a European Common law. ${ }^{44}$ Bellamy's argument, that this flexibility suits the "EU's character as an evolving polity and must be enhanced not rejected," ${ }^{45}$ has a relevance for a gender analysis. The struggle for women's full acceptance is a continuing project at a substantive, if not formal level, within the European Union. In this respect a constitution that fixes neither the current polity nor regime ${ }^{46}$ makes sense for the women's movement. Any change to the extant constitution should recognise in its form the need for ongoing legitimating discourse and likewise provide space for agenda setting.

\section{The Treaty Establishing a Constitution for Europe}

This section considers why women's participation in the process should have been specifically addressed. It then addresses feminist lobbying around the Constitutional Treaty, initially as an attempt to get more women involved,

41 Walker, "Constitutional Pluralism" (2000); Bellamy, Richard, "Which Constitution For What Kind of Europe? : Three Models of European Constitutionalism" Paper for CIDEL Workshop "Constitution Making and Democratic Legitimacy in the EU" London, 12-13 ${ }^{\text {th }}$ November 2004, p.1 5-6; Wieler, "On the Power of the Word" (2002); Castiglione, Dario "From The Charter to the Constitution of Europe?: Notes on the Constitutionalisation Process in the EU," Queens Papers on Europeanisation No. 5/2002; Paul Craig, "Constitutions, Constitutionalism, and the European Union" (2001) 7 ELJ 125.

42 Walker, "Constitutional Pluralism" (2002) at 343.

43 Richard Bellamy, "Which Constitution For What Kind of Europe?: Three Models of European Constitutionalism" Paper for CIDEL Workshop "Constitution Making and Democratic Legitimacy in the EU" London, 12-13 ${ }^{\text {th }}$ November 2004 p.6. He suggests that the former accords with the French constitution and the latter with the German.

44 ibid., 15-6.

45 ibid., at 3. Bellamy uses the example of women as a previously excluded group and notes that historically women struggled for changes to both regimes and polities in order to be accepted as full subjects in national constitutions.

46 ibid., at 3. 
then in order to try to change the content of the drafts and finally in connection with the campaign for a "no" vote.

\section{Women and Constitution Making}

International law recognises the right to participate in governance. ${ }^{47}$ At one point it was believed that these rights to participate in democratic processes did not apply to the constitution making process because constitutions were a pre-condition but not a part of democratic governance. But Vivien Hart argues that rights to participate in constitution making have crystallised. So constitution making should be subjected to the same democratic participatory processes as other areas of governance. ${ }^{48}$ Since it is recognised that women have a right to participate in governance then this should include their right to participate in constitution making..$^{49}$ Moreover the desirability of including women in such processes is formally recognised at an international level through development programmes, ${ }^{50}$ United Nations ${ }^{51}$ and World Bank literature and programmes. ${ }^{52}$

Mere physical presence of women within the constitution-making convention, what Hannah Pitkin calls symbolic or descriptive representation,,$^{53}$ is not a guarantee that gender issues will be raised and discussed. But research shows that where women are represented in a "critical mass" ${ }_{4}$ changes in political culture, discourses and policy take place. ${ }^{55}$ It is therefore important to include women's voices in constitution making processes so that the outcome of constitutional debate reflects the aspirations and concerns of women.

But irrespective of any tangible outcomes it is suggested that the process of entering into constitutional debate itself can have a stimulating and mobilising effect on campaigns for women's equality. Merely entering the

47 UNHR (1948) Article 21 ICCPR Article 25. In relation specifically to women, African Charter on Humans and Peoples Rights (1981) Article 13, Convention on the Political Rights of Women (1952) Preamble, CEDAW Article 7 and Article 8. But these rights do not appear in the European Convention on Human Right's and Fundamental Freedoms (1952) or the more recent EU Charter of Fundamental Rights of the European Union. (2000).

48 Vivien Hart, "The Right to Participation in Constitution-Making: A Response to Frank" 2007 forthcoming.

49 ibid. Though the scope of such rights is not clear.

50 Chinkin, Christine, Gender Mainstreaming in Legal and Constitutional Affairs: A reference Manual for Governments and Other Stakeholders (Commonwealth Secretariat, London, 2002).

51 Hart, Democratic Constitution Making, United States Institute of Peace (USIP) Special Report July 2003, p.7. See also in relation to women's representation in post-conflict situations UN Security Council Resolution 1325 (2000).

52 http://www.worldbank.org.

53 Hanna Fenichel Pitkin, The Concept of Representation, (1967), p.81.

54 Dahlerup was one of the first people to use this term in relation to women's representation. Drude Dahlerup, (ed.), The New Women's Movement: Feminism and Political Theory in Europe and the USA (SAGE, 1986).

55 Dalerup, The New Women's Movement (1986); Norris, Pippa, Women Politicians Transforming Westminster, (1996) 49 Parliamentary Affairs 89; High-Pippert, Angela and John Comer, Female Empowerment: The Influence of Women Representing Women (1998) 194 Women and Politics 53. 
debate raises the profile of women's rights and the status of women within the wider polity. ${ }^{56}$ Melissa Haussman notes that both in Canada during the Charter debates, which had a favourable outcome for women's groups, and during and after United States of America Equal Rights Amendment discussions, which did not lead to constitutional change, women's status and profile were raised. ${ }^{57}$ Democratic participation in constitution-making is also recognised as affecting the subsequent use of constitutional provisions by both citizens $^{58}$ and the judiciary. ${ }^{59}$ It also raises debate in political institutions. Therefore involvement in the process itself generates positive discourses which act both internally on the women's movement and externally on constitutional institutions.

Despite widespread recognition of the importance of ensuring gender debate in constitutional development and change, it is certainly not always addressed. While women were major players in South Africa and other recent constitutional processes, ${ }^{60}$ the inadequate inclusion of women in the Iraq constitutional process was widely criticised. ${ }^{61}$ But there were two reasons why it was expected that women would be specifically included in the deliberations. Firstly because the European Union had commitments to gender mainstreaming and gender representation. ${ }^{62}$ Second because the

56 Gill Vickers, Why Should Women Care About Constitutional Reform, in David Schneiderman, (ed.), Conversation Among Friends: Interdisciplinary Conference on Women and Constitutional Reform (Edmonton, Centre for Constitutional Studies, University of Alberta, 1991).

57 Melissa Haussman, Feminist Strategies for Equality Rights in the U.S. and Canada, in Jill Bystydzienski, (ed.), Women Transforming Politics: Worldwide Struggles for Empowerment (1992).

58 Louise Carbert, (1996), "With, Without, and In Spite of an ERA: Legal Equality and Public Opinion in Canada, United States and Japan." Paper presented at American Political Science Association San Francisco, California, September 1996.

59 In relation to the way that constitutional Articles and principles are interpreted. Roland Penner, "The Canadian Experience with the Charter of Rights: Are There Lessons for the United Kingdom?"[1996] PL Spring 104.

60 Alexander Dobrowolsky and Vivien Hart, "Introduction: Women, New Politics and Constitutional Change" in Dobrowolsky and Hart, Women Making Constitutions (2003), p.1-19.

61 Mona Imam, "Draft Constitution Gained But an Important Opportunity Was Lost.” USIP Briefing October 2005, http://www.usip.org/pubs/usipeace_briefings/ 2005/1011_draft.html; Johnathon Morrow, "Iraq Constitutional Process II: An Opportunity Lost" USIP Special Report No. 155, December 2005, http://www.usip.org/pubs/specialreports/sr155.html.

62 Lombardo notes that both the Treaty of Amsterdam 1997 Articles 2 and 3.2 express a commitment to promoting gender equality in all EU activity and that the Third Fourth and Fifth Commission's Action Programmes for Equal Opportunities Between Men and Women and Commission's Communication (96) 67 on Incorporating Equal Opportunities for Women and Men Into All Community Policies and Activities" also stress the importance of this Lombardo, Emmanuela, "Integrating or setting the Agenda? Gender Mainstreaming in the European Constitution-Making Process." (2005) Project MUSE Fall 412 at 416. Moreover Council Recommendation 96/694EC is specific in suggesting that there should be gender balance in all the decision making processes of the commission and Commission Decision 2000/407/ EC. 19 June recommends that women make up $40 \%$ of all commission expert groups and committees. Leon, Margarita; Mercedes 
project had as one of its stated aims the greater legitimation of Europe through the inclusion of the European citizenry. Constitutions have two principal qualities as descriptors of the arrangements for government, first as official existing power maps and secondly as a 'set of principles for legitimate government." ${ }^{3}$ The Laeken Declaration ${ }^{64}$ which initiated the process developing the Constitutional Treaty required it to be driven by the search for the latter. The project was initially identified as something to further change not to support the status quo. Laeken presented the Convention on the Future of Europe - the body which was to draft the Constitutional Treaty - as an answer to the European Union's “crisis of legitimacy ... particularly in relation to its capacity to satisfy the expectations of its citizens." ${ }^{65}$ Moreover comparative analysis of the literature on gender and constitutions suggests that it is at times where there is a search for legitimation that women and other marginalized groups may have more chance of gaining power in the processes of constitutional change. ${ }^{66}$ The need to legitimise the process leads to a more inclusive politics, at least during the period of change. ${ }^{67}$

So it was surprising that there was little attempt to ensure that women were involved in the constitutional process. ${ }^{68}$ Diaz and Millns, drawing on their comparative work in this area, note that it is recognised within member states that affirmative measures are always necessary to ensure gender equality in political representation. ${ }^{69}$

\section{Women in the Convention on the Future of Europe}

Once it was known that there would be a Convention on the Future of Europe, the Women Citizens of Europe Network (RCE) called for balanced representation of men and women in its formulation and decision making

Mateo Diaz and Susan Millns, "Engendering the Convention: women and the Future of the European Union" (2003) March The Federal Trust, European University Institute Florence, www.fedtrust.co.uk/uploads/constitution/06_03.pdf. at 3; A range of other reports and recommendations from Parliament, Council and Commission in favour of Parity democracy within the EU institutions also subsist see Eropa.eu.int/futureeu/documents/other/oth001101_en.pdf.

63 Harden, Ian "The Constitution and Its Discontents" (1991) 21 British Journal of Political Science 489 at 491 . Though there will always be some tensions between these two elements.

64 See particularly Part II http://europa.eu.int/constitution/futurum/documents /offtext/doc151201_en.htm. Adopted December 15 2001.

65 Jo Shaw, "Europe's Constitutional Future" [2005] PL 132 at 141.

66 Dobrowolsky, Alexandra, "Women, Constitutionalism and Contestation" in Dobrowolsky and Hart, Women Making Constitutions (2003), p.236.

67 This was the case in Canada before the 1984 Charter and in Australia during the debate on a republic. See Helen Irving, "The Republic is a Feminist Issue" (1996) 52 Feminist Review 87. Is it also exemplified in a range of other recent processes see Alexandra Dobrowolsky, and Vivien Hart, Introduction: Women, New Politics and Constitutional Change in Dobrowolsky and Hart, Women Making Constitutions (2003).

68 The convention was likened to the US founding fathers convention in 1787, which is noted for its exclusion of women and black citizens from the process.

69 Diaz, Mercedes Mateo and Susan Millns, "Parity Power and Representative Politics: The Elusive Pursuit of Gender Equality in Europe." (2004) 12: 3 FLS 279 at 301. 
processes and they drew attention to the fact that women had been poorly represented in the Convention which drew up the European Union Charter of Fundamental Rights. $^{70}$ From October 2001, The European Women's Lobby (EWL) and the European Women Lawyers Association (EWLA) ran letterwriting campaigns to decision makers asking for parity in the participation of men and women in the convention and the Presidium. ${ }^{71}$ Yet only in January 2002, did Chairman of the Convention, Giscard d"Estaing draw government's attention to the importance of "ensuring that women are wellrepresented on our convention." This was on the last line of his letter to heads of government requesting a final list of delegates. ${ }^{72}$ This was too late and the Convention, composed of representatives from the European Parliament and national governments and national parliaments comprised just seventeen women out of a hundred and five full delegates. ${ }^{73}$ Only two women were sent by governments and six by national parliaments the remainder came from among MEP's. Later, when chided about the lack of women in the convention, Giscard rather lamely replied that women would make up for their lack of numerical presence through the force of their personalities. ${ }^{74}$

Millns and Diaz note that when the convention members were then divided between the Praesidium, Secretariat and Working groups, only the secretariat was gender balanced. ${ }^{75}$ They argue that this was no accident and that the allocation of women to the Secretariat which was largely administrative and supportive of convention work, rather than to the Praesidium, agenda setting and taking final decisions, or the working groups, mirrors usual gender divisions in employment in Europe. ${ }^{76}$ Initially two women were appointed to the Praesidium, but when Ana Palaccio, the Spanish MEP left ${ }^{77}$ only Gisela Stuart UK MEP remained. Percentages in the working groups varied from $5 \%$ in the Group on Subsidiarity to $30 \%$ in the Group on National Parliaments. ${ }^{78}$ Men headed ten of eleven working groups. ${ }^{79}$ There were slightly more women among the alternates sent to the convention, twentyfour out of a hundred and five. ${ }^{80}$ Indeed, Baroness Scotland, the only member

70 Europa.eu.int/futureeu/documents/other/oth001101_en.pdf Professor Alice Brown, expert advisor to the Gender and Equality group of the Scottish Constitutional Convention was one of the signatories this letter.

71 EWL Press Release on Convention Campaign 4/4/2002; "Chairpersons of Convention's Working Groups: Statement of EWLA” Brussels, 16 May 2002.

72 Hoskyns, Catherine, "Gender Equality and the Convention - A Comment" (2003) The Federal Trust online Paper 08/03 www. fedtrust.co.uk.

73 Cathryn Hoskyns suggests that by the time the European Women's Lobby and the European Parliaments Women's committee started to lobby on composition of this convention it was too late to have influence. ibid.

74 Lombardo, Integrating or setting the Agenda, (2005) at p.423. She quotes "Elles compensent cette situation d"infērioritē numerique par la forte personalitē de beaucoup d"entre elles." (The poor translation in the text is by Dr. Skeet).

75 Diaz, Mercedes Mateo and Susan Millns, Women and the Constitutional Future of the European Union (2004) at 9

76 ibid., at 9.

77 March 2003.

78 Millns and Diaz, Women and the Constitutional Future (2004) at 9.

79 Gisela Stuart was President of the Working Group on National Parliaments.

80 Millns and Diaz, Women and the Constitutional Future (2004), p.11 Table 5 figs. for 21 October 2002 
of an ethnic minority in the convention attended as an alternate. ${ }^{81}$ But the Convention initially limited their involvement, though after intense lobbying this was relaxed. ${ }^{82}$

Once it was understood that the composition was fixed, the lobbies turned attention to the question of representing gender within the Convention through other means. EWL launched a "Where are the Women?" postcard campaign..$^{83}$ They also set up email links to women within the convention to support those women taking up gender issues in the talks and provided shadow directives and comprehensive feedback on the treaty drafts. ${ }^{84}$ EWLA made 12 written contributions through the drafting life of the Constitutional Treaty's, providing detailed written proposals and comment on changes. ${ }^{85}$ The European Parliamentary committee on "Women's Rights and Equal Opportunities" also made written submissions. In addition they drew up a list of concerns ${ }^{86}$ and set up two conferences in 2002 providing alternative forums for women to speak directly to Convention members. ${ }^{87}$ All Convention members were invited but Anna Karamanou, Chair of the Committee, considered the response from the male-dominated Convention members both "disappointing and worrying" 88

The absence of a "critical mass" $" 89$ of women is evidence at least of failure of the Convention to concern itself with gender issues if not evidence of actual discrimination against women. ${ }^{90}$ Women's initial disappointment with the selection process for the Convention became a disappointment with the way that women's concerns were represented in the debate and drafting of the Constitutional Treaty.

81 Discussion with Annette Lawson, Women's European Lobby. "A New Model Europe - Citizens at the Centre Conference" Westminster University London, $15^{\text {th }}$ September 2005.

82 If alternates had been fully incorporated into proceedings from start, as they were in the proceedings for discussion of the Charter, then Schonlau believes that this would have boosted the range of political representation within the proceedings. Justus Schonlau, "The Membership of the Convention: Issues of Representation and Legitimacy" (2004) Paper for Cidel Workshop "Constitution-making and Democratic Legitimacy in the EU" London, 12-13 ${ }^{\text {th }} 2004$.

83 EWL Press Release 27/2/2002 "Convention on the Future of Europe: Where are the Women?", Le Fil D'Ariane Gender Equality Newsletter of the European Parliament, www.europarl.eu.int/comparl/femm.newsletter/newsletter0, at 2.

84 www.womenlobby.org.

85 www.ewla.org.

86 Praesidium member Ana Palacio delivered it to the convention.

8722 May and 2 October.

88 Introductory Speech by Anna Karamanou, Chairwoman of the Committee on Women's Rights and equal Opportunities of the European Parliament. Extraordinary Meeting Spring 2003 www.europarl.europa.eu/comparl/femm/ ccec/meetings/athens2003/karamanou_en.pdf.

89 Dahlerup was one of the first people to use this term in relation to women's representation. Drude Dahlerup, (ed.), The New Women's Movement: Feminism and Political Theory in Europe and the USA (London, SAGE, 1986).

90 Phillips presents this view in relation to formal political arenas. Anne Phillips, "Democracy and Difference: Some Problems for Feminist Theory" (1992) 63 Political Quarterly 79. 


\section{Content of Draft and Final Treaty}

The main structure of the Constitutional Treaty remained the same through the different drafts. It is divided into four main parts: Part I Principles and objectives; Part II the European Charter of Fundamental Rights as amended for the Constitutional Treaty; Part III functioning of the institutions and internal and external policies including the internal market, security and justice and foreign policy; Part IV details revision procedures and entry into force and repeal of earlier treaties and includes protocols to the Constitutional Treaty. ${ }^{91}$ A number of authors have given gender audits of draft and versions and the final treaty. ${ }^{92}$ It is not intended to replicate these here but instead to draw on them to evidence the continuing dissatisfaction with the drafting process and to raise points which were later taken up by women campaigning for a "no" vote.

The Preliminary Draft of the Constitutional Treaty was presented in October 2002. It contained no references at all to equality between men and women in Part I Principles and Objectives. Moreover the document was not drafted in gender inclusive language and either used the generic masculine, or was gender blind in many places. ${ }^{93}$ Gisela Stuart suggested that the absence of equality from Part I in the first draft was just an oversight, a mistake. ${ }^{94}$ But the EWL suggested that the text indicated "an alarming backlash in the field of gender equality". 95

There was no responsibility allocated for ensuring mainstreaming within each group and separate working group on gender. ${ }^{96}$ Hoskyns also cites as evidence of women's absence, and lack of influence in the Convention, the failure to set up a working group on Social Europe at the start. ${ }^{97}$ A group was eventually set up in November 2002 following a vigorous campaign led by Anne Lancker, one of the few female members of the Convention. ${ }^{98}$ The late establishment of the committee placed great pressure on work and meant the opportunity for true engagement and consultation was lost. Both Hoskyns and Shaw suggest that this lack of concern for the Social Europe was also evident in all subsequent drafts of the Constitutional Treaty. ${ }^{99}$ In the event this late established group was the only one in the European Convention which openly discussed gender issues. ${ }^{100}$

91 There are also a number of annexes and declarations following the Treaty.

92 For instance see Hoskyns, "Gender Equality and the Convention" (2003) and Millns and Diaz, Women and the Constitutional Future (2004).

93 Despite strong lobbying from the EWLA and the EWL see "Linking EU Competencies with Women's Rights" 6/6/2002 http://www.womenlobby.org

94 Hoskyns, "Gender Equality," (2003), at 3.

95 EWL "Comments on the Preliminary Draft Constitutional Treaty." 11/11/2002 http://www.womenlobby.org.

96 EWLA Second Contribution and Fifth Contribution to the Convention p.6.

97 Hoskyns, "Gender Equality" (2003) at 2.

98 Jo Shaw, "A Strong Europe is a Social Europe" The Federal Trust Online Paper 05/03 February 2003. at 2 . This group had a very tight re-mit and was only able to meet five times in a very short space of time in order to achieve its seven point mandate.

99 Jo Shaw, "A Strong Europe is a Social Europe" (2003); Hoskyns, "Gender Equality" (2003), at 2.

100 Lombardo, "Integrating or Setting the Agenda (2005). 
When the Second Draft of Articles 1-16 was produced, $6^{\text {th }}$ February 2003, equality between men and women appeared but only in I.3, under the Aims of the Union rather than in 1.2 which set out its Values. While gender equality might be "read obliquely" into the value of human dignity and human rights, Millns and Diaz argue that this gives insufficient protection. ${ }^{101}$ The significance of Gender Equality appearing in 1.2 is that 1.2 is referred to by many subsequent sections and provides a checklist of democratic criteria for aspirant countries to meet as well as informing the future policies of the European Union. Therefore many critics suggested that the reference in 1.3 was not only weak in its construction but was also weak in relation to its position in the treaty. The EWL described this as "a betrayal of the women of Europe". ${ }^{102}$ The failure to express equality as a "higher order value" marked a retrograde step from the Treaty of Amsterdam. ${ }^{103}$ Gender equality must be expressed as a transversal principle as in the TEC so that the duty to ensure gender equality applies to all the Union's activities. ${ }^{104}$ There was also criticism that where the principle of non-discrimination in relation to nationality was referred to (Article 1.4 .2 of the Constitutional Treaty) no mention was made of sex and none to any other categories like sexuality which were previously presented in Article 13 of the TEC. ${ }^{105}$ Amongst other criticisms was the failure to mention gender equality as a separate area in the division of competencies Article 12 - it was presumably subsumed under social policy. ${ }^{106}$

The Convention on the Future of Europe only produced the draft constitutional treaty, and like any other European Union Treaty final content would ultimately be determined by a conference of the representatives of national governments. It is not unusual for positive constitutional changes for women to be effected through a combination of elite group activity and mass mobilisation ${ }^{107}$ and, in this case, the continued lobbying of the InterGovernmental Conference by the EWL and EWLA brought some successes. For instance the efforts of Baroness Scotland in achieving change were notable. ${ }^{108}$ The EWLA noted that as a result of the IGC discussion equality was placed in Article I.2 as a value, Article III.2 (116) on gender mainstreaming was to apply to all policies and in relation to this Article the

101 Diaz and Millns, Women and The Constitutional Future (2004) at 15.

102 EWL - Letter to the Convention 27 May 2003 http:// www.womenlobby.org/site. In fact Hoskyns, "Gender Equality," (2003), at 3 notes that this was positioning was discussed Giscard d' Estaing argued for it to appear as a value but was defeated by a majority in the Praesidium.

103 Sylvia Walby, "The EU and Gender Equality: Emergent Varieties of Gender Regime," (2004) 11:1 Social Politics 4 at 7.

104 Network of Legal Experts on the Application of Community Law on Equal Treatment between men and women. "The European Convention and Gender Equality: Observations on the Draft Articles of the Constitutional Treaty," www.ewla.org/wf_dl/convent_network.doc, at 2.

105 Hoskyns, "Gender Equality," (2003), p.3.

106 ibid., at 3.

107 Kome, Penny, The Taking of Twenty-Eight: Women Challenge the Constitution (Women's Press, Toronto, 1983).

108 Discussion with Annette Lawson, Women's European Lobby. “A New Model Europe - Citizens at the Centre Conference" Westminster University London, $15^{\text {th }}$ September 2005. 
IGC gave a declaration on fighting domestic violence. ${ }^{109}$ While this latter provision was welcomed by feminists it has no binding legal status and the EWL amongst others would have preferred a stronger stand on all forms of violence against women. ${ }^{110}$ After lobbying by the High Commissioner for National Minorities, a further positive addition was a reference to minority rights in Article 1.2 as a value of the Union. Reference to minority rights had been completely absent from the drafts up until this point. ${ }^{111}$ Moreover no minority rights clause appears in the Charter of Fundamental Rights annexed to the Constitutional Treaty. ${ }^{112}$

Negative changes also occurred. Protocol 9 was annexed to Treaty Article 62. This states that "Nothing in the Treaty establishing a Constitution for Europe or in the Treaties and Acts modifying or supplementing it shall affect the application in the territory of Malta of national legislation relating to abortion". This pre-empted any possible interpretation of the dignity and equality values in 1.2 applying to this aspect of women's reproductive rights. ${ }^{113}$ No other general protection for reproductive rights was added into the Treaty. IGC changes also removed a positive requirement, in Article I26.2 of the Convention draft, stating that member states would have to put forward three names for Commissioners in which "both genders were represented." 114

Overall, Millns and Diaz, assessing the gender output of the Convention, suggest it is "fairly negligible although not quite as impoverished as it looked set to be earlier. ..." 115 They conclude that the Treaty illustrates the "paucity of interest in and commitment to gender equality at the highest constitutional level." 116

\section{Campaigns against the Treaty}

Specific groups and individuals among the EWL membership adopted antitreaty positions, but the two main European women's lobby groups, EWLA and EWL, did not express a position in relation to voting on the Treaty. ${ }^{117}$ Instead both issued statements expressing their opinion on both positive aspects and deficiencies of the Treaty, ${ }^{118}$ and the EWL continued to inform

109 "Resolution of EWLA On the Treaty Establishing A Constitution for Europe" http://www.ewla.org/wf_content/506.html.

110 EWL June 21 2004, "IGC Outcome June 17-18" at 1.

111 Krzystof Drewewicki, High Commissioner on National Minorities, "A Constitution For Europe: Enshrining Minority Rights - Words Can Make Worlds of Difference" (2005) 19:2 OSCE Magazine March, at 1.

112 ibid.

113 Feminist Assembly of Madrid, "Women and the European Constitution," (2005) IV Online Magazine: IV365- March, http://www.internationalviewpoint.org/print _article.php3?id_article $=576$.

114 EWL 21 June 2004. "IGC final Outcome June 17-18, 2004" at 1; Stop Violence Against Women.

115 Diaz and Millns, "Women and The Constitutional Future"(2004) at 18.

116 ibid., at 18.

117 Of course not all women in Europe were to be offered this opportunity in any case.

118 Resolution of EWLA on the Treaty on a Constitution For Europe 17 and 18 March 2005 Brussels. http://www.ewla.org/wf_content/506.html; EWL IGC 
women about the content of the Treaty so that they could make an informed choice when voting. ${ }^{119}$

Other feminist groups across Europe campaigned in their own countries against the Treaty but the campaign was also trans-national and was intensified in order to influence women in France and Holland to vote "no" and end the Constitutional Treaty on behalf of all women across Europe. ${ }^{120}$

In addition to looking at the absence of positive gender initiatives, campaigns against the treaty also addressed other aspects they believed to have negative impact for women. Women's groups had been among those who successfully lobbied for removal of explicit references to the JudeoChristian heritage of Europe in the Values of the Union. But reference still remained to the "religious . . inheritance" of Europe, ${ }^{121}$ Article 1.52 singles out churches over and above any other social group in Europe for regular dialogue. Women Living Under Muslim Laws (WLUML), London European Assembly for Women's Rights and Association pour la Tax Tobin pour l"Aide aux Citoyens France Women, who campaigned against the Treaty were particularly concerned that this reference to religion undermined the principle of secularism in the European Union at a time when women in minority groups were under increasing pressure from disadvantageous governance by religious family law. ${ }^{122}$ Therefore they considered women who were "other" would not be treated equally. The Feminist Assembly of Madrid, Women Towards a Different Europe and Catholics for Free Choice argued that this privileged consultation with churches on Union policy ran contrary to "equality between the sexes" and the right for women to make free decisions about divorce, abortion, contraception and protection against AIDS, and threatened the rights of homosexuals and lesbians. ${ }^{123}$ Other groups suggested that reference to religious heritage and the use of the word "Churches" inferred a preference for the established Christian churches of Europe and constituted Muslim and other religions as outside or other within

Outcome June 17-18 2004 http://www.womenlobby.org/site/1abstract.asp? DoclD $=190 \& v 11 D$.

119 EWL Communication Strategy for the European Constitution, Briefing Document on the Treaty Establishing a Constitution For Europe http://www.womenlobby. org/site/1abstract.asp?DoclD=194\&v11D.

120 "The European Feminist Initiative Acts in Priority for a NO to The Constitution and for a YES To Another Europe Memorandum" Women's Centre For Democracy and Human Rights http://www.globalizacija.com/doc_en/e0032 dok.htm, at 1; See also the campaign by Les Penelopes http://penelopes.org and the campaign by Women Towards A different Europe, with contributions from Swedish feminists who led the Swedish campaign against monetary union.

121 The humanist inheritance is also referred to.

122 WLUML - Femmes Sous Lois Musulmanes, "Europe: European Feminist Initiative for "NO" to the Constitution." 24/11/2004 http://wwwwluml.org /english/newsfulltext.shtml; European Women: ATTAC France Statement "For Women's Rights, For Equality, No to this Europe." IV Online Magazine: IV365March 2005 http://www.internationalviewpoint.org/print_article.php3?id_article $=576$.

123 This was expressly stated at the London European Assembly for Women's Rights 15/10/04 http://wwwwluml.org/english/newsfulltext.shtml. 
Europe. ${ }^{124}$ Further critiques that the Treaty fostered "otherness" centred on the conflation of European Union citizenship with nationality within member states: there was concern for the rights of the many women immigrants in the European Union. ${ }^{125}$

Some feminist groups saw incorporation of the Charter, even with its restricted legal scope, as positive. Yet those arguing for the "no" vote were concerned that the Charter, already criticised as insufficient to properly support women's rights in Europe, ${ }^{126}$ had been subjected to such "drafting adjustments" as to limit its scope still further. Moreover the Charter had no provision for future amendment to improve or extend rights within it. ${ }^{127}$ The Constitutional Treaty therefore set in stone provisions that women had been unable to participate in developing and which they considered to be inadequate. ${ }^{128}$

A further major thrust against the Constitutional Treaty was led by green and socialist feminists in Women Towards a Different Europe (WTDE), European Feminist Initiative (EFI) and the socialist women in - Association pour la Tax Tobin pour l'Aide aux Citoyens (ATTAC) ${ }^{129}$ These groups and others argued that Part III of the treaty ${ }^{130}$ fixed a neo-liberal economic structure, which would force privatisation, re-structuring, cutbacks on welfare and would effectively harm women as the poorest citizens in Europe. Moreover they argued that this treaty would remove whole swathes of national and European social policy permanently from the reach of democratic influence. ${ }^{131}$

124 Certainly COMECE - The Catholic Bishop's Conference in Europe believe the wording still recognises and privileges Christianity within Europe, "The Treaty Establishing a Constitution for Europe: Elements for Evaluation" 11 March 2005. http://www.comece.org/upload/pdf/pub_const_treaty_050311_EN.

125 Feminist Assembly of Madrid, "Women and the European Constitution", in IV Online Magazine: IV365- March 2005 http://www.internationalviewpoint.org/ print_article.php3?id_article=576.

126 Letter to Convention on the Charter of European Rights from European Women's Lobby, 18th February 2000, Charter 4132/00 Contribution 27.

127 Spilotopoulos, Sophia, "From Nice to the Draft Constitutional Treaty and Beyond: Which Charter and Which Fundamental Rights?" Paper given at ECSADK 24-25 September 2004 "The Future of Europe"; also criticism from EWLA, "Fifth Contribution of EWLA on the Future of the Union" EWLA website at 5.

128 For instance the Feminist Assembly of Madrid, "Women and the European Constitution", in IV Online Magazine: IV365- March 2005 http://www.internationalviewpoint.org/print_article.php3?id_article=576 noted the lack of re-productive rights and they there was provision for marriage but not for divorce.; A further argument was that any women's rights protection might be weakened by determinations from the ECJ which balanced Charter rights against economic objectives. Haralanova, Christina, Les Penelopes, "The EU Constitution and the Consequences for Women". 17 October 2004 http://www.penelopes.org/anglais/ximpression.php3?type=article.

129 Association for the Taxation of Financial Transactions for the Aid of Citizens.

130 This part was only released to the public some months after Parts I and II.

131 "The EU Constitution and the Consequences for Women," Report on the Workshop Organised by Women Towards A different Europe, European Social Forum London $16^{\text {th }}$ October 2004, at 1 www.socialrights.org; "The EU Constitution and the Consequences for Women", Les Penelopes http://www.penelopes.org/Anglais/xarticle.php3?id_article=1152; George, Susan 
The WTDE and EFI also campaigned against what they perceived as the militarism inherent in the Treaty. After the French "no" vote a declaration announced, "The victory of the "No" in France is that of the Left, proEuropean, alternative -globalist, feminist and democratic No, against neoliberalism and war." 132 Although peace was mentioned as an aim of the European Union, the Constitutional Treaty constitutionalised support for NATO, ${ }^{133}$ and committed members to increase military budgets. ${ }^{134}$

Women's groups in opposition were acutely aware that the Constitutional Treaty had been drafted by a convention that had not actively sought women's representation. Groups who attended consultations and lobbied for specific social protections and guarantees felt that they had not been listened to. Criticism was also levelled at the failure to clearly state a position on violence against women, the absence of protection for reproductive rights, ${ }^{135}$ and the lack of gender perspective in other areas of "health, culture and education."136 Moreover there were concerns that specific enumeration and protection of social rights including maternity and paternity rights was absent. ${ }^{137}$

In relation to all this there was added anger that the treaty purported to be the "will of the people." 138

It is just unrealistic to dismiss the rejection of the Constitutional Treaty by all these groups as anti-Europe sentiment. Rather they were sceptical that the Constitutional Treaty actually conserved and built on all that was good about Europe. Instead they considered it an attempt to set in stone exclusionary social and economic modes and would remove their potential to influence the development of Europe in a way that reflected the concerns of women. The campaign against the Constitutional Treaty was presented as a fight to prevent "dominating male and neo-liberal power" from being "carved in marble' for several decades." 139

and Erik Wesslius, "Why French and Dutch Citizens are Saying NO" (2005) redpepper http://www.redpepper.org.uk/europe/x-jun2005-constitution2.htm.

132 Declaration of the European Conference, Paris, 25th June, 2005 http://www.socialniprava.info/article1235.html.

133 Cassen, Bernard, "Attac Against The Treaty," (2005) 33 May/June New Left Review 27 at 31

134 Eva Cruells, 16 October 2004, Les Penelopes "Feminist European Initiative for the No to the Constitution." http://penelopes.org.

135 ASTRA and the Centre for Reproductive Rights detail breaches in International Rights in the EU and explain why this safeguard is so important for women's rights generally. www.astra.org.

136 Lombardo, "Integrating or setting the Agenda" (2005) at 421.

137 Network of Parliamentary Committees for Equal Opportunities for Women and Men in the European Union. Extraordinary Conference, Athens 31 March 2003.

138 See Les Penelopes; Social Rights Bulgaria; Women Towards a Different Europe.

139 "The European Feminist Initiative Acts in Priority for a NO to The Constitution and for a YES To Another Europe Memorandum" Women's Centre For Democracy and Human Rights http://www.globalizacija.com/doc_en/ e0032dok.htm, at 1 . 


\section{The Treaty Establishing a Constitution for Europe in Relation to Constitutional Theory and Gender}

Grass roots opposition by women's groups to the Constitutional Treaty was not articulated in terms of constitutional theory yet the specific and practical concerns raised by the feminist "no" campaign show synergy with critiques on the direction of this constitutional project raised by European constitutionalists. These critiques also accord with forms of constitutions and in particular with the ideological critiques of "modern constitutionalism" discussed at the start of paper. ${ }^{140}$ All focus on concern with the use of the constitutional form as a fetish, with process or lack of it in constitutionmaking and with the type of constitutional form used to frame the treaty provisions. This section addresses these points.

Firstly, "fetish". It is suggested that the Constitutional Treaty does not look like a constitution. ${ }^{141}$ It is long, 448 Articles, and has a large quantity of appendices. It lacks the usual style of preamble expected in a constitution, ${ }^{142}$ and the aspirations expressed lack the clarity expected in a genuine constitution. ${ }^{143}$ Moreover in the 202 pages of the main text, Cassan notes that there are 176 instances of the word "bank" and its derivatives. "The word market appears 88 times, trade competition 29 capital 23 and commodity 11."144 This linguistic focus on the market is also not redolent of constitutional language. If "Constitution" were removed from the title of a "Treaty Establishing a Constitution for Europe" then Weiler suggests the treaty would be indistinguishable from any other. ${ }^{145}$ From this it must be inferred that the word "Constitution" is an attempt to imbue the resulting treaty with a legitimacy which it could not otherwise have gained. This use of the constitution as "fetish" standing above ordinary political processes is argued to be a striking feature of the closed modern constitutional form. ${ }^{146}$

There was no obligation on the Convention on the Future of Europe to attempt to draft a constitutional treaty. The convention could have kept a more open discussion, focussed on democratic reforms and carried out consultation exercises to engage Europeans on in the future of Europe. Indeed Bogdonor suggests a number of democratic reforms which could be carried without even any Treaty changes. ${ }^{147}$ The convention chose instead to

140 Judith Squires, Liberal Constitutionalism, Identity and Difference (1996) XLIV Political Studies 620; Young, Polity and Group Difference (1989); Anne Phillips, The Politics of Presence: The Political Representation of Gender, Ethnicity and Race (Oxford, OUP, 2003); James Tully, 'Strange Multiplicity” (1995).

141 Weiler, On the Power of the Word (2005) at 175; Vernon Bogdanor, Legitimacy, Accountability and Democracy in the European Union, A Federal Trust Report January 2007 www.fedtrust.co.uk at 11; Bernard Cassan, The Referendum on the EU Constitution - Europe : No Is Not a Disaster, (2005) April , Le Monde Diplomatique, http://mondediplo.com.

142 Weiler, On the Power of the Word (2005) at 175.

143 Bogdanor, Legitimacy, Accountability and Democracy (2007).

144 Cassan, The Referendum on the EU Constitution (2005).

145 Weiler, On the Power of Word (2005) at 176.

146 Walker, "The Idea of Constitutional Pluralism," (2002); Tully, Strange Multiplicity (1995).

147 Bogdanor, Vernon, Legitimacy, Accountability and Democracy in the European Union. 
invoke the rhetoric of constitution-making and made reference to the Philadelphia convention 1787 in order to present the treaty as a defining moment in European history. ${ }^{148}$ While the 1787 process can not be described as "a democratic exemplar for today" ${ }^{149}$ Nevertheless its invocation calls for the resultant processes, drafts, and final document, to be judged, against the norms and standards applicable to our current understandings of constitutionmaking. ${ }^{150}$

\section{Process}

Although this paper principally addresses the disaffection of the women's movement in Europe with participation in the constitutional treaty process this disaffection is also illustrative of wider disillusion and disengagement with the process.

The initial failure to ensure women's direct representation in the convention need not have been fatal to the sense of legitimacy for women. Other means of representation and engagement might have sufficed. For instance gender concerns might have been addressed by setting up a Gender Working Group in the Convention on the Future of Europe, but this approach was rejected. At the October 2002 Women's Convention on Building a Democratic Europe, ${ }^{151}$ Presidium member Gisela Stuart was asked why there was no working group on gender, she said that she had not supported such a group because of the risk that women's issues would become marginalised. ${ }^{152}$ But this was not the experience of the Scottish Constitutional Convention 19911994, which despite smaller proportion of women, only $10 \%$, established a working group on gender issues that successfully influenced the work of all the other groups in that convention. ${ }^{153}$

Consultation and the co-option of advisors are other recognised ways of increasing representation in constitution-making bodies. ${ }^{154}$ But as stated earlier, Convention on the Future of Europe members did not all take up their invitations to attend alternative forums.

Good engagement generally with civil society can compensate for underrepresentation of women and other political minorities within formal bodies. ${ }^{155}$ These groups tend to be better represented within social

148 Walker, Neil, "After the Constitutional Moment" The Federal Trust for Education and Research, Online Paper 32/03, 2003 p.3 http://www.fedtrust.co.uk/ eu_constitution.

149 Hart, Democratic Constitution-Making (2003) p.4.

150 Weiler, On the Power of the Word (2005).

151 Set up by the European Parliament Committee on Women's Rights and Equal Opportunities. October 2002.

152 Though she also accepted the difficulties of mainstreaming equality within the Convention www.europarl.eu.int/comparl/femm.newsletter/newsletter02- at 2.

153 Final Report of the Women's Issues Group of the Scottish Constitutional Convention, National Archives of Scotland Uncatalogued Records of the Scottish Constitutional Convention 1989-1996 Document Ref GD 498/1/6.

154 Pitkin, Hanna Fenichel, The Concept of Representation (Berekley University of California Press, 1967), p.76; Young, Iris Marion, Inclusion and Democracy (Oxford, OUP, 2000).

155 Young, Inclusion and Democracy (2000), p.194. 
movements than in formal politics. ${ }^{156}$ Yet representation in these senses was also poor and civil society had only limited access to the convention. So despite its remit to engage with the citizens of Europe and infuse the proceedings with legitimacy the Convention on the Future of Europe is widely criticised for failing to fulfil the spirit of the Laeken remit by properly engaging society. ${ }^{157}$ In fact Jean Luc Dehanne the person appointed by Giscard d" Estaing to liaise with civil society initially gave "the impression that he might ignore calls for a structured dialogue with civil society," altogether and he only set up structures for engagement after intense lobbying. ${ }^{158}$ Moreover it was not considered feasible to allow the Social Affairs Working Group to consult widely with civil society and NGO's because it was set up so late. ${ }^{159}$

This lack of engagement is illustrative of Weiler's criticism that this constitution-making process saw democracy solely as the end of the "European construct" rather than as a means. ${ }^{160}$ The focus was on capturing a constitutional moment instead of seeing the importance of constitutional discourse and process. ${ }^{161}$ Yet for women and other political minorities it is essential that constitution-making allows for the complex process of mobilisation of grass roots and elite activity necessary to gain a hearing for their claims. ${ }^{162}$

Certainly those initially in favour of a written or codified constitution for Europe, like Habermas, saw this opportunity for deliberation and project building as key to the constitution-making process. Habermas believed this could have "catalytic effect" on Europe's future providing an "unique opportunity for trans-national communication," 163 which could be used to develop a European citizenship and vision. ${ }^{164}$ Habermas understandings of what he calls a "European Demos" very much require this development. He explicitly bases the idea of an EU citizenship on the development of shared civic values rather than on conceptions of community based on the

156 Young, Inclusion and Democracy; Lindsay, Isobel, "The Voluntary Sector" in Crick, Bernard, (ed.). Citizens: Towards Citizenship Culture (Oxford, Blackwell, 2001).

157 Berger, Nicolas, "Participatory Democracy: Organised civil Society and the New Dialogue" (2004) July Online Paper 09/04, The Federal Trust For Education and Research. Berger argues that the meetings that were arranged had little political impact but great symbolic significance, at 5; Stuart, Gisela, "The Making of the European Constitution" (2003) Fabian Ideas, 609 Fabian Society 2003, at 25.

158 Berger, Participatory Democracy (2004) at 5.

159 Shaw, "A Strong Europe is a Social Europe" (2003) at 2. Though Shaw does say that many members listened carefully and made substantial use of submissions from civil society groups.

160 Weiler, On the Power of the Word (2005) at 183

161 Walker, After the Constitutional Moment (2003); Shaw, "Europe's Constitutional Future" (2005) at 150.

162 Dobrowolsky and Hart, Women Making Constitutions (2003), Tully, Strange Multiplicity (1995).

163 Habemas, Jurgen, "Why Europe Needs a Constitution" (2001) 11 New Left Review 5.

164 ibid., at 16-17. 
"accidental connexions" of shared history religion or ethnicity. ${ }^{165}$ In this way he argues for an inclusive not exclusive conception of the people.

\section{Form}

The Treaty represented a radical change in form to the Constitution of the European Union. Prior to the Constitutional Treaty theorists were discussing and celebrating the open texture of European Union constitutional architecture. ${ }^{166}$ Yet the Treaty rejects the distinctively open and arguably more dynamic constitutionalism and instead clothes the EU in "modernist" form. Effectively the more flexible, discursive and political constitution is swapped for a rigid and codified model. So at exactly the time when there is pressing need for discussion on essential questions relating to who lives together in Europe and how we live together in Europe ${ }^{167}$ the Constitutional Treaty appears to constrain debate. Weiler argues it does this because it usurps the fundamental principle: that it is only the continued debate itself which serves to legitimise the "discipline" of the EU over national political forums. ${ }^{168}$ Yet the desire on the part of women to take part in and continue the debate can be seen prior to the "no" votes through the Budapest Declaration $^{169}$ and through organisations like Women Towards A Different Europe. The focus of these debates are precisely the areas sidelined by the constitutional process: diversity, equality, social inclusion and discussion on the shape and form, including economic form, that the European Union should take. ${ }^{170}$

The presentation of an European Union constitution in the form contained in the Constitutional Treaty also poses questions for women seeking constitutional change in the future. Where there is no formal process for constitutional amendment the need to legitimate change rests on the deliberations and the process of change itself. Though as we see this was not properly recognised by the Convention on the Future of Europe. In codified constitutions the formal amendment process may be seen as sufficient legitimation itself and the ability to orchestrate and achieve change may therefore be limited to existing elites. ${ }^{171}$ For example, in the United States of America women's campaigners have repeatedly failed to gain an equal rights

165 ibid.

166 De Burca, Grainne and Joanne Scott, Constitutional Change in the EU: From Uniformity to Flexibiliy (Hart, Oxford, 2000).

167 Jo Shaw, "Europe's Constitutional Future" (2004).

168 Weiler, "On the power of the Word" (2005) at 183

169 The Budapest Declaration : Building European Civil Society through Community Development, March 282004.

170 The experience of exposure to markets especially for women from newer accession countries, has caused hardship. "Gender Equality in the EU- Two Years After Accession of New Member States: Unifem Consultation, Concluding Statement UNIFEM 2006", www.unifem.org; Another group researching specifically in this area is Women's Network in Development Europe - WIDE www.eurosur.org/wide/home.htm. See The Enlarged European Union and Its Agenda for a 'Wider Europe': What Consideration of Gender Equality? (WIDE 2005).

171 See Harrison, Cynthia, "Heightened Scrutiny": A Judicial Route to Constitutional Equality for US Women" in Dobrowolsky and Hart, Women Making Constitutions (2003), p.155-172. 
amendment to the constitution. ${ }^{172}$ Moreover we can compare the ability of women's groups to get representation in the 1982 constitutional discussions in Canada, where there was a perceived need to legitimate through process rather than form and contrast this with the difficulty for women in gaining access to the process at Meech Lake after the Canadian constitution was codified. ${ }^{173}$ This does not necessarily preclude future feminist support for some codification of an EU constitution. But women need to ensure not only that the content of any codified documents reflects their interests but also that the constitutional form is underpinned by the principles of "mutual recognition" and deliberation so that they and other political minorities, and groups from civil society are guaranteed access and representation to deliberations for change.

As stated above the Convention assumed an already constituted people with a common purpose. In this again the Constitutional Treaty also shows fixity, invoking accidental connections and referring back to the already constituted "peoples of Europe" rather than forward to a shared purpose. In relation to this Loughlin's sees the threatening concept of a "kulterkampf" 174 and Weiler asks whether "the unanswerable question is whether the discourse of formal constitutionalism, the very power of the word [constitution]. . ., will rob Europe of this ethos of tolerance that was its defining grundnorm." 175

\section{Conclusion}

This paper examined the Treaty Establishing a Constitution for Europe from the perspective of gender and constitutional change and noted the gender gap in the referenda which stopped its progress to ratification. The paper first considered how changes to constitutions and changes to constitutional form can have a gendered dimension. It then examined the extent to which women had participated in and influenced the process of change and content outcomes of the Constitutional Treaty, before examining the specific campaigns against the treaty by women's groups. The final sections linked the basis for the feminist campaigns back to the theoretical critiques of the type of constitutionalism for gender equality and showed the synergy between the two.

The focus of campaigns were ostensibly on the absence of women in the constitutionalising processes and on the content of the Constitutional Treaty but feminists were also questioning something larger, the way of determining the future of Europe and of deciding the parameters of further political debate: the exclusivity of that constitutional form itself.

In as much as the campaigns were negative about the Constitutional Treaty, a rejection of a hollow constitutional rhetoric ${ }^{176}$ of participation and equality;

172 ibid.

173 Shelagh Day, "Speaking For Ourselves" in Kenneth McRoberts and Patrick Monahan, The Charlottetown Accord, the Referendum, and the Future of Canada (1993), p.58-72.

174 Martin Loughlin "The constitution of Europe: The new Kulturkampf?” (2004) European Law Review 557-569.

175 Weiler, "On the power of the Word" (2005), at 186.

176 Weiler suggested that this rhetoric might prove to be the Constitutional Treaty's undoing. ibid. 
166 Northern Ireland Legal Quarterly [Vol. 58, No. 2]

then they were also positive in expressing interest and concern for a closer Europe based on social values. ${ }^{177}$ If Habermas "unique opportunity for transnational communication" 178 was not after all achieved through the Convention on the Future of Europe perhaps the trans-national campaigns against the Constitutional Treaty may have "catalytic effect" 179 in forming a value-based European citizenry and developing the constitution.

177 Less than $3 \%$ of no votes were against further enlargement.

178 Habermas, "Why Europe Needs A constitution" (2001) at 16-17.

179 ibid. 